Plant Tissue Cult. \& Biotech. 31(1): 25-34, 2021 (June)

CBangladesh Assoc. for Plant Tissue Culture \& Biotechnology

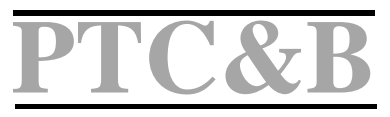

\title{
In vitro Propagation of Two Tannia (Xanthosoma sagittifolium (L.) Schott) Cultivars from Shoot Tip Explants
}

\author{
Eyasu Wada* and Tileye Feyissa ${ }^{1}$ \\ Department of Biology, College of Natural and Computational Sciences, Wolaita Sodo University, \\ P.O.Box 138, Wolaita Sodo, Ethiopia
}

Key words: Explant, Micropropagation, Shoot tip, Tannia

\begin{abstract}
This study was carried out to develop an in vitro propagation protocol for two tannia (Xanthosoma sagittifolium (L.) Schott) cultivars (green and purple), using shoot tip explants. Shoots were best initiated on the MS supplemented with $2.0 \mathrm{mg} / \mathrm{BAP}$. The highest number of shoot per explant (green tannia: $4.56 \pm 0.35$ purple tannia: $4.83 \pm 0.26$ ) was recorded on the MS supplemented with $2.5 \mathrm{mg} / \mathrm{BAP}$ and $0.5 \mathrm{mg} / \mathrm{NAA}$. The longest shoot (green tannia: $3.92 \pm 0.40 \mathrm{~cm}$ and purple tannia: $4.36 \pm 0.46 \mathrm{~cm}$ ) was recorded on the MS supplemented with $5.0 \mathrm{mg} / \mathrm{BAP}, 1.0 \mathrm{mg} / \mathrm{Kn}$ and $0.5 \mathrm{mg} /$ NAA. The highest number of roots per shoot (green tannia: $6.00 \pm 0.74$ and purple tannia: $5.83 \pm$ 0.49 ) was obtained on the medium containing $2.0 \mathrm{mg} / \mathrm{IBA}$. The results of this study showed that tannia could efficiently be propagated in vitro by incorporating appropriate concentration of PGRs.
\end{abstract}

\section{Introduction}

Tannia (Xanthosoma sagittifolium (L.) Schott) is one of the main edible aroids in many tropical areas of the world. The cormles and young leaves are the usable parts of the crop (Giacometti and Leon 1994). Tannia is contributing to the household food security in the rural communities of south and southwestern parts of Ethiopia. However, its cultivation is constrained by scarcity of planting materials, because the propagules of tannia, such as cormels or their fragments are used as food. Preserving tannia under field condition is

*Author for correspondence: <eyasuwada@gmail.com>. Institute of Biotechnology, College of Natural and Compuational Sciences, Addis Ababa University, P.O.Box 1176, Addis Ababa, Ethiopia.

DOI: https://doi.org/10.3329/ptcb.v31i1.54108 
risky since diseases or natural catastrophes can cause the loss of genetic resources (Onyeka 2014). In vitro propagation technique is a possible solution to the major problems of vegetative propagated plants associated with pathogen dissemination and subsequent loss of vigor and productivity (Paul and Bari 2007), health and quality (Ko et al. 2008; Vilchez et al. 2009) and planting material scarcity (Solomon et al. 2010).

In vitro regeneration is an efficient method to propagate quality planting materials that can substantially improve production rate (Caula et al. 2008). It involves using smaller propagules and substantially faster multiplication rate than the conventional multiplication methods (Sama et al. 2012). Plant cells, tissues or organs can be produced in large numbers where all the individuals have the same genetic constitution as the stock parent although somaclonal variation may sometimes occur (George et al. 2008).

Production of a large number of plants of selected germplasms is the main prerequisite for establishment of plantations for $e x$-situ conservation and improvement of plants (Siddique and Anis 2009). Multiplication of many clonally propagated species in a short time is among many advantages of micropropagation systems (Panell 1984). There are some reports that have generated information to use for in vitro propagation of tannia through refining culture media and plant growth regulators (PGRs) compositions (Paul and Bari 2007, Sama et al. 2012; Niemenak et al. 2013). However, the ideal concentration and combination of PGRs required for in vitro propagation differ from species to species, genotype to genotype and explant source (Obidiegwu 2015). The composition of PGRs needs to be established accurately to achieve an effective rate of multiplication of a genotype (Gomes et al. 2010). There was no protocol that was adequately developed for routine micropropagation for tannia cultivars growing in Ethiopia. This justifies looking for an efficient in vitro propagation protocol in order to obtain higher benefits from the cultivation of the crop. Shoot tip culture is a useful and an expanding method to rapidly obtain a large numbers of propagules. Therefore, this study was aimed to develop an efficient in vitro propagation protocol for green tannia and purple tannia cultivars using shoot tip explants.

\section{Materials and Methods}

The sprouts of green tannia and purple tannia cultivars were collected after six weeks of planting in greenhouse under natural photoperiods, maintaining temperature at $25 \pm 2^{\circ} \mathrm{C}$. Plants were watered as needed with tap water. The roots were removed and the corm was scrubbed with a brush, $0.5 \%$ sodium hypochlorite and soap under tap water. The lower portion of the corm was cut off, leaving about $3 \mathrm{~cm}$ corm shoot tip. The leaf stalk was trimmed to 2.0 to $3.0 \mathrm{~cm}$. The shoot tip explant was gently scrubbed with toothbrush using double distilled water, rinsed with double distilled water, followed by washing with $70 \%$ ethanol for five min and rinsed with double distilled water for three to four times. Then, the explant was placed in a clean beaker containing a solution of $1.5 \%$ sodium hypochlorite and two drops of Tween-20. The beaker was placed on a magnetic 
stir bar plate and stir gently for $45 \mathrm{~min}$. The solution was poured off and the explant was rinsed with sterilized double distilled water and taken into the laminar flow hood. The outer leaves were removed until the inner cleaner section was appeared. The explants were then trimmed to $1.0 \mathrm{~cm}$, rinsed three to four times with sterile double distilled water, $70 \%$ ethanol for $30 \mathrm{sec}, 1 \%$ sodium hypochlorite for $1 \mathrm{~min}$ and sterile double distilled for three to four times.

About 1.0 to $2.0 \mathrm{~cm}$ shoot tips comprising apical meristem with some leaf primordia and some corm tissue at the base were used for shoot initiation on MS medium supplemented with different concentrations of BAP. The number of initiated shoots was recorded beginning from fourth day of culture and presented as percentage of shoot initiation. The number of shoots and leaves per explant, and shoot length were recorded after two weeks of culture initiation to select the best shoot initiation medium.

The initiated explants were cultured on 20 different combinations of BAP, Kn and NAA. PGRs free medium was used as control to screen for an optimal shoot multiplication medium. The number of shoots and leaves per explant, and shoot length were recorded after three subsequent cultures at two week interval.

The in vitro propagated shoots were transferred into a fresh PGRs free MS medium for two weeks, before conducting the rooting experiment, in order to avoid any carry over effect of PGRs. Then, the shoots were cultured on MS medium supplemented with different concentrations of IBA or NAA for root induction. PGRs free medium was used as a control. The percentage of root formed shoots, number of roots per shoot and root length were recorded after three weeks of culture.

After being in rooting medium for three weeks, the root induced shoots were removed from the culture vessel and the roots were washed in double distilled water. Sixty plantlets (30 plantlets of each of green tannia and purple tannia) were planted in forest soil, coffee husk and sand in the ratio of 2:1:1, respectively. All plantlets were covered with a plastic cloche for three days before being left open in greenhouse. The number of survived plants was recorded after two weeks of acclimatization.

The experiments were laid in a completely randomized factorial design with PGRs as one factor and cultivars as another factor. Three explants per culture vessel and six replications per treatment were used for shoot initiation, shoot multiplication and root induction experiments. Cultures were incubated and monitored in growth room of $12 \mathrm{~h}$ photoperiod under light intensity of $40 \mu$ mole $^{-2} \mathrm{~s}^{-1}$ provided by cool white fluorescent lamps at a temperature of $25 \pm 2^{\circ} \mathrm{C}$. Statistical analysis was carried out using Minitab 17.1 (2013). Treatment separation was performed using Tukey's mean comparison test at a probability level of $\mathrm{p}<0.05$.

\section{Results and Discussion}

The shoot tip explants responded differently to BAP concentrations. The percentage of shoot formation ranged from $83.56 \%$ to $100 \%$, which was better response than that of 
Castro (2006) who obtained the highest initiated explants (83\%) of tannia in the MS medium containing $0.5 \mathrm{mg} / \mathrm{BAP}$ and $1.0 \mathrm{mg} / \mathrm{IAA}$. The number of shoots per explant and shoot length on the PGRs free medium and the medium containing different concentrations of BAP were not statistical different (Table 1). However, 100\% explant induced shoots with relatively higher number of shoots, leaf numbers and longer shoots, which look more comfortable with the medium composition and turned green within 4 days of culture, were produced on the medium containing $2.0 \mathrm{mg} / \mathrm{BAP}$.

Table 1. Effect BAP on shoot initiation of green tannia and purple tannia from shoot tip.

\begin{tabular}{lllllll}
\hline \multirow{2}{*}{ Green tannia } & \multicolumn{5}{c}{ BAP concentration $(\mathrm{mg} \Lambda)$} \\
\cline { 2 - 6 } & 0.0 & 1.0 & 2.0 & 3.0 & 4.0 & 5.0 \\
\hline Shoot initiation (\%) & 84.19 & 84.19 & 100.00 & 94.44 & 94.44 & 89.30 \\
Shoot no/explant & $1.50 \pm 0.21^{\mathrm{a}}$ & $2.00 \pm 0.42^{\mathrm{a}}$ & $2.44 \pm 0.47^{\mathrm{a}}$ & $2.22 \pm 0.20^{\mathrm{a}}$ & $1.89 \pm 0.25^{\mathrm{a}}$ & $1.55 \pm 0.07^{\mathrm{a}}$ \\
Leaf no/explant & $1.56 \pm 0.18^{\mathrm{b}}$ & $2.06 \pm 0.17^{\mathrm{ab}}$ & $3.11 \pm 0.13^{\mathrm{a}}$ & $2.78 \pm 0.28^{\mathrm{a}}$ & $2.67 \pm 0.19^{\mathrm{a}}$ & $2.89 \pm 0.20^{\mathrm{a}}$ \\
Shoot length (cm) & $1.53 \pm 0.21^{\mathrm{a}}$ & $2.08 \pm 0.15^{\mathrm{a}}$ & $2.17 \pm 0.15^{\mathrm{a}}$ & $2.11 \pm 0.24^{\mathrm{a}}$ & $1.78 \pm 0.44^{\mathrm{a}}$ & $1.92 \pm 0.21^{\mathrm{a}}$ \\
\hline Purple tannia & & & & & & \\
Shoot initiation (\%) & 83.56 & 89.30 & 100.00 & 94.90 & 94.90 & 89.38 \\
Shoot no/explant & $1.94 \pm 0.25^{\mathrm{a}}$ & $2.22 \pm 0.16^{\mathrm{a}}$ & $2.50 \pm 0.25^{\mathrm{a}}$ & $2.28 \pm 0.16^{\mathrm{a}}$ & $2.22 \pm 0.13^{\mathrm{a}}$ & $1.83 \pm 0.17^{\mathrm{a}}$ \\
Leaf no/explant & $1.86 \pm 0.10^{\mathrm{b}}$ & $2.36 \pm 0.07^{\mathrm{ab}}$ & $3.41 \pm 0.43^{\mathrm{a}}$ & $3.08 \pm 0.20^{\mathrm{a}}$ & $2.97 \pm 0.09^{\mathrm{a}}$ & $3.1 \pm 0.18^{\mathrm{a}}$ \\
Shoot length (cm) & $1.72 \pm 0.41^{\mathrm{a}}$ & $2.08 \pm 0.18^{\mathrm{a}}$ & $2.33 \pm 0.16^{\mathrm{a}}$ & $2.17 \pm 0.20^{\mathrm{a}}$ & $1.94 \pm 0.10^{\mathrm{a}}$ & $1.83 \pm 0.28^{\mathrm{a}}$ \\
\hline
\end{tabular}

Data are given as means \pm standard error of means (SE); Means that do not share a letter in superscript in the same row are significantly different at $p<0.05$ by Tukey mean comparison.

The longest shoots were obtained on the medium supplemented with $5.0 \mathrm{mg} / \mathrm{BAP}$ $+1.0 \mathrm{mg} / \mathrm{Kn}+0.5 \mathrm{mg} / \mathrm{NAA}$. Statistically, the same length but better quality shoots were also obtained on the medium containing $2.5 \mathrm{mg} / \mathrm{BAP}$ and $0.5 \mathrm{mg} \Lambda \mathrm{NAA}$. Maximum shoot number per explant (green tannia: $4.56 \pm 0.35$ purple tannia: $4.83 \pm 0.26$ ), looks more comparable with the medium composition (Fig. 1), was also obtained on the later MS medium composition (Table 2). This indicates importance of using BAP (2.5 $\mathrm{mg} \Lambda$ ) in combination with and NAA $(0.5 \mathrm{mg} /)$ for shoot multiplication of tannia as far as its objective is to obtain the maximum number of shoots with the best length in order to facilitate its management during acclimatization.

Maximum leaf number per explant (green tannia: $4.67 \pm 0.41$ and purple tannia: $4.94 \pm$ $0.50)$ was obtained on medium containing $1.0 \mathrm{mg} / \mathrm{BAP}+0.25 \mathrm{mg} / \mathrm{Kn}$. The longest shoots (green tannia: $3.92 \pm 0.40 \mathrm{~cm}$ and purple tannia: $4.36 \pm 0.46 \mathrm{~cm}$ ) were obtained on the medium containing $5.0 \mathrm{mg} / \mathrm{BAP}+0.5 \mathrm{mg} / \mathrm{NAA}+1.0 \mathrm{mg} / \mathrm{Kn}$ (Table 2). These were better achievement than previous reports by different authors (Paul and Bari 2007; Solomon et al. 2010, Sama et al. 2012). The differences among these studies could be 
attributed to variations in genotype, culture medium and environmental factors such as $\mathrm{CO}_{2}$ and light intensity.
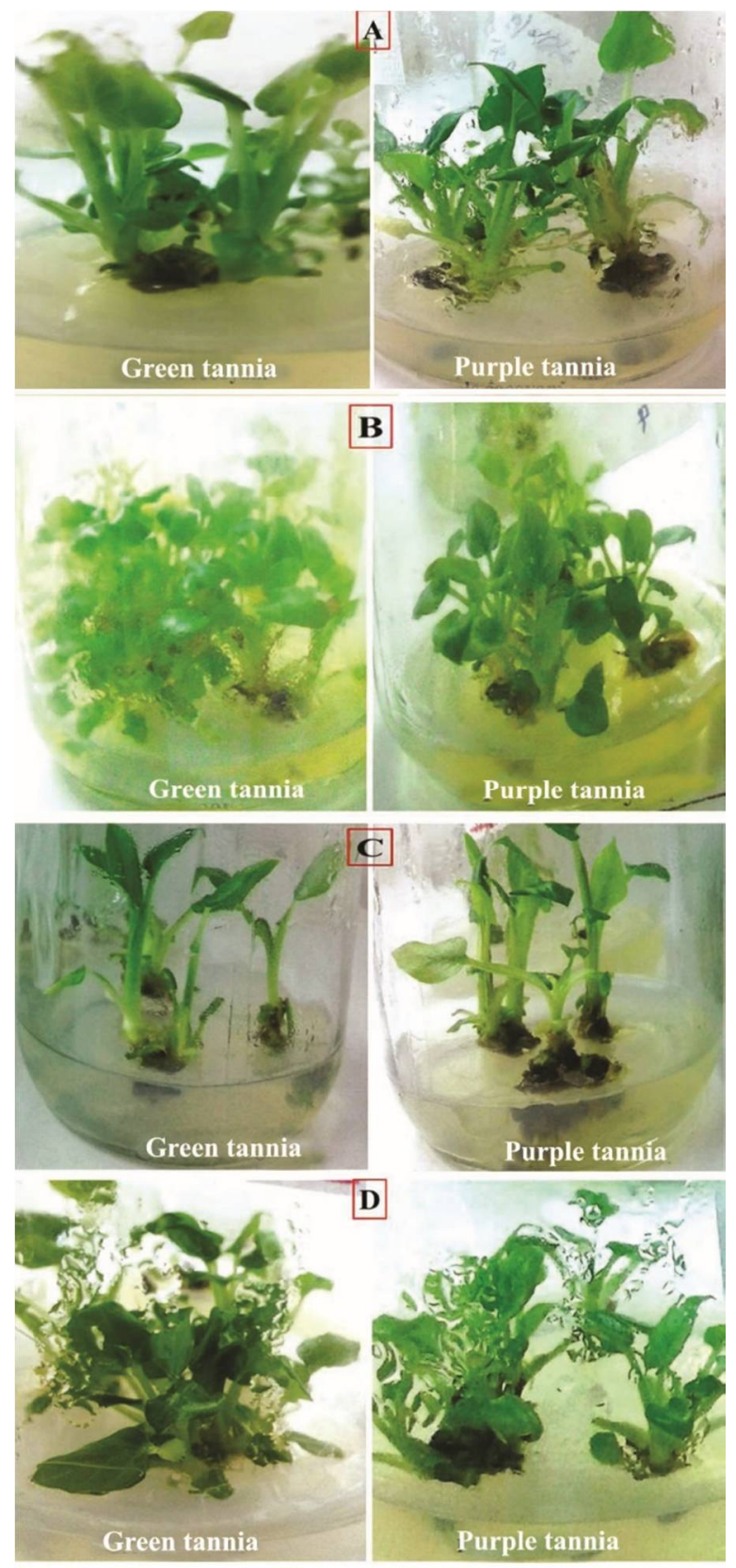

Fig. 1. Green tannia and purple tannia on different multiplication media. (A) $2.5 \mathrm{mg} A \mathrm{BAP}+0.5$ $\mathrm{mg} / \mathrm{NAA}$; (B) $1.0 \mathrm{mg} / \mathrm{BAP}+0.25 \mathrm{mg} / \mathrm{Kn}$; (C) $5.0 \mathrm{mg} / \mathrm{BAP}+1.0 \mathrm{mg} / \mathrm{Kn}+0.5 \mathrm{mg} / \mathrm{NAA}$; (D) control (without growth regulator). 


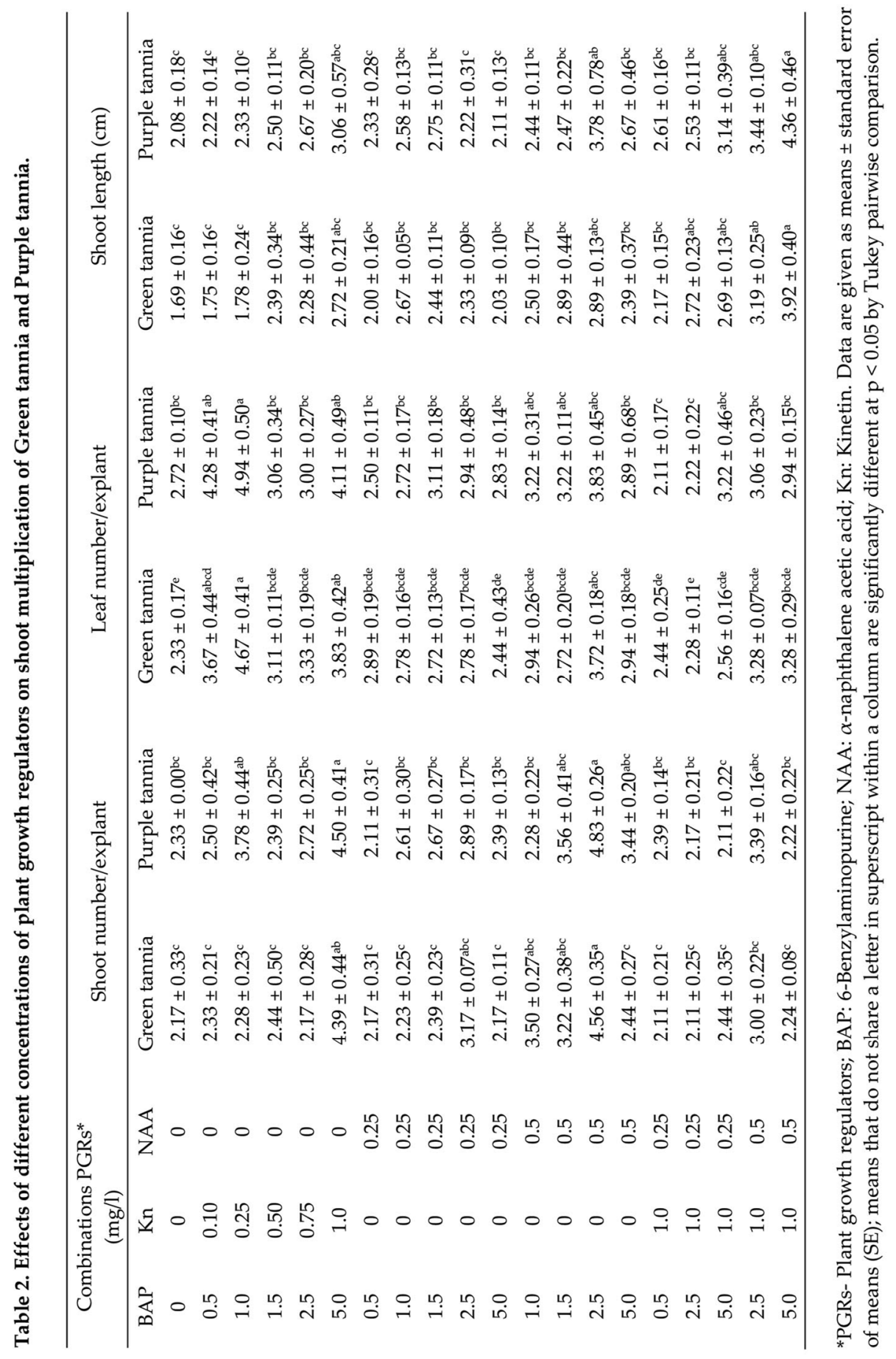


The number of roots per shoot and root length were influence by the different concentrations of IBA and NAA. The highest root initiation (93.3\%) for green tannia was obtained on the medium containing $2.0 \mathrm{mg} / \mathrm{IBA}$, whereas for purple tannia, it was $86.7 \%$ on the MS medium containing $2.0 \mathrm{mg} / \mathrm{NAA}$. The highest number of roots per shoot (green tannia: $6.00 \pm 0.74$ and purple tannia: $5.83 \pm 0.49$ ), and the longest roots (green tannia: $5.94+0.71$ and purple tannia: $6.44+0.99$ ) were obtained on the medium supplemented with $2.0 \mathrm{mg} / \mathrm{IBA}$ (Fig. 2A-B). Related responses were reported by other authors (Paul and Bari 2007, Wokabi 2012). Relatively lower number of roots was obtained on PGRs free MS medium and MS medium supplemented with lower concentration IBA $(0.25 \mathrm{mg} \Lambda$ ) (Table 3). Paul and Bari (2007) found the lowest number of roots in a medium containing no PGRs. Most of the explants foremed roots with subsequently sub-culturing on MS medium containign different concentration of PGRs (Wokabi 2012).

Table 3. Effect of IBA and NAA on root induction of green tannia and purple tannia.

\begin{tabular}{llcccccc}
\hline & & \multicolumn{2}{c}{$\begin{array}{c}\text { Root forming shoots } \\
(\%)\end{array}$} & \multicolumn{2}{c}{ No. of roots shoot } & \multicolumn{2}{c}{ Root length $(\mathrm{cm})$} \\
\cline { 3 - 8 }$(\mathrm{mg} /)$ & $\begin{array}{l}\text { NAA } \\
(\mathrm{mg} \Lambda)\end{array}$ & $\begin{array}{c}\text { Green } \\
\text { tannia }\end{array}$ & $\begin{array}{c}\text { Purple } \\
\text { tannia }\end{array}$ & $\begin{array}{c}\text { Green } \\
\text { tannia }\end{array}$ & $\begin{array}{c}\text { Purple } \\
\text { tannia }\end{array}$ & $\begin{array}{c}\text { Green } \\
\text { tannia }\end{array}$ & $\begin{array}{c}\text { Purple } \\
\text { tannia }\end{array}$ \\
\hline 0 & 0 & 43.3 & 33.3 & $0.94 \pm 0.34^{\mathrm{b}}$ & $0.56 \pm 0.07^{\mathrm{c}}$ & $0.61 \pm 0.22^{\mathrm{c}}$ & $0.39 \pm 0.10^{\mathrm{b}}$ \\
0.25 & 0 & 66.7 & 53.3 & $1.28 \pm 0.25^{\mathrm{b}}$ & $1.28 \pm 0.30^{\mathrm{bc}}$ & $2.00 \pm 0.48^{\mathrm{bc}}$ & $1.67 \pm 0.37^{\mathrm{b}}$ \\
0.50 & 0 & 76.8 & 76.8 & $2.11 \pm 0.85^{\mathrm{b}}$ & $2.94 \pm 0.67^{\mathrm{b}}$ & $2.75 \pm 0.26^{\mathrm{b}}$ & $2.33 \pm 0.29^{\mathrm{b}}$ \\
1.0 & 0 & 83.3 & 83.3 & $2.72 \pm 0.94^{\mathrm{b}}$ & $3.28 \pm 0.67^{\mathrm{b}}$ & $4.06 \pm 0.11^{\mathrm{ab}}$ & $3.00 \pm 0.45^{\mathrm{b}}$ \\
2.0 & 0 & 93.3 & 93.3 & $6.00 \pm 0.74^{\mathrm{a}}$ & $5.83 \pm 0.49^{\mathrm{a}}$ & $5.94 \pm 0.71^{\mathrm{a}}$ & $6.44 \pm 0.99^{\mathrm{a}}$ \\
3.0 & 0 & 76.8 & 76.8 & $2.39 \pm 0.50^{\mathrm{b}}$ & $3.28 \pm 0.66 \mathrm{~b}$ & $3.94 \pm 0.75^{\mathrm{ab}}$ & $2.83 \pm 0.84^{\mathrm{b}}$ \\
0 & 0.25 & 33.3 & 23.3 & $1.00 \pm 0.37^{\mathrm{b}}$ & $0.50 \pm 0.28^{\mathrm{c}}$ & $1.61 \pm 0.61^{\mathrm{bc}}$ & $1.22 \pm 0.50^{\mathrm{b}}$ \\
0 & 0.50 & 73.3 & 60.0 & $2.06 \pm 0.13^{\mathrm{b}}$ & $2.00 \pm 0.23^{\mathrm{bc}}$ & $1.94 \pm 0.42^{\mathrm{bc}}$ & $1.89 \pm 0.21^{\mathrm{b}}$ \\
0 & 1.0 & 76.8 & 70.8 & $2.22 \pm 0.32^{\mathrm{b}}$ & $3.06 \pm 0.26^{\mathrm{b}}$ & $2.22 \pm 0.42^{\mathrm{bc}}$ & $2.17 \pm 0.45^{\mathrm{b}}$ \\
0 & 2.0 & 86.7 & 86.7 & $2.56 \pm 0.62^{\mathrm{b}}$ & $3.33 \pm 0.38^{\mathrm{b}}$ & $3.00 \pm 0.60^{\mathrm{bc}}$ & $2.50 \pm 0.58^{\mathrm{b}}$ \\
0 & 3.0 & 70.0 & 53.3 & $1.67 \pm 0.12^{\mathrm{b}}$ & $1.89 \pm 0.76^{\mathrm{c}}$ & $2.17 \pm 0.64^{\mathrm{bc}}$ & $2.44 \pm 1.11^{\mathrm{b}}$ \\
\hline
\end{tabular}

Means that do not share a letter in superscript within a column are significantly different at $p=0.05$ by Tukey pairwise comparison. Data are given as means \pm standard error of means (SE).

Upon acclimatization, $23(76.7 \%)$ green tannia and $25(83.3 \%)$ purple tannia were survived, which were, however, low response compared to the reports of Onokpise et al. (1992 and1999) who obtained 100\% survival with acclimatization studies. The relative lower survival percentage could be due to the genotypic variation of tannia among two studies. Previously, Hazarika et al. 2006 reported that genotype can influence the ability of regenerated plants to withstand the ex vitro growing conditions. Regarding the green 
tannia and purple tannia, no considerable differences were observed for the shoot multiplication, root induction and acclimatization parameters. This indicates any perceived difference was due to random error and the genetic variation that existed between the two may be limited to be differentially influenced by the medium compositions. The in vitro propagated tannia after two weeks of acclimatization in greenhouse are shown in Fig. 2C.
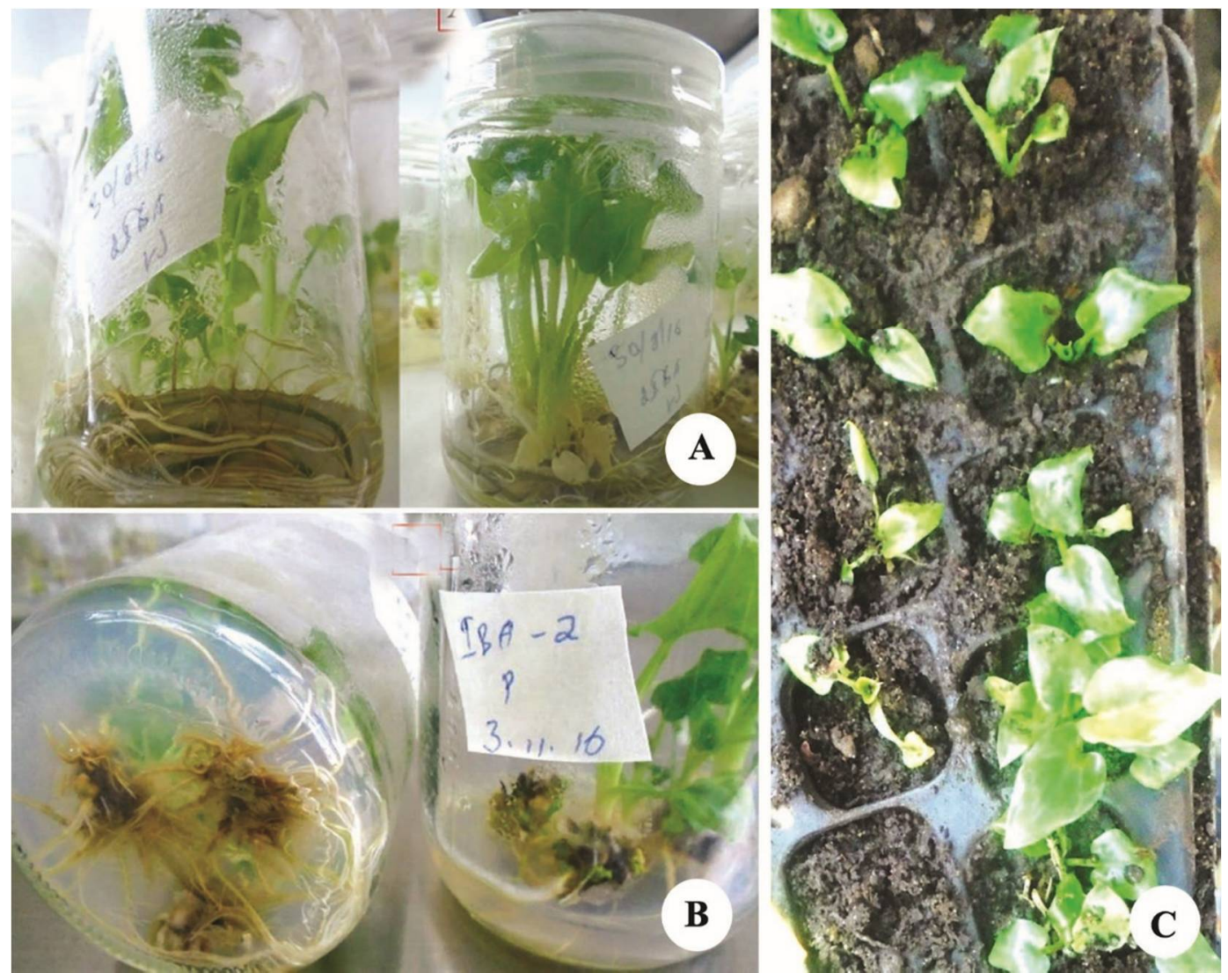

Fig. 2. In vitro rooting and acclimatization of tannia. Development of roots at the base of shoots cultured on MS supplemented with $2.0 \mathrm{mg} /$ IBA. A. Green tannia and B. Purple tannia, C. In vitro propagated plants after two weeks of acclimatization in the greenhouse.

The results of the present study showed that tannia (Xanthosoma sagittifolium (L.) Schott) could efficiently be propagated in vitro by incorporating appropriate concentration of PGR on the MS medium for the phases of shoot initiation $(2.0 \mathrm{mg} /$ $\mathrm{BAP})$, shoot multiplication ( $2.5 \mathrm{mg} / \mathrm{BAP}+0.5 \mathrm{mg} / \mathrm{NAA})$ and root induction $(2.0 \mathrm{mg} /$ IBA). This protocol can be used to supplement the farmers' conventional methods of propagation of tannia. Further work is suggested to evaluate the cormel yields of the 
multiplied tannia plants on the field and to investigate growth condition of tannia for $e x$ situ conservation.

\section{Acknowledgements}

The authors acknowledge Wolaita Sodo University, Addis Ababa University and Areka Agricultural Center for Financial and material supports.

\section{References}

Castro GR (2006) Studies on cocoyam (Xanthosoma spp.) in Nicaragua, with emphasis on dasheen mosaic virus. Doctoral Thesis, Swedish University of Agricultural Sciences, Uppsala, Sweden.

Caula A, Bey R and Robert N (2008) Plant Propagation: Concept and Laboratory Exercise, CRC press, USA.

George EF, Hall MA and Klerk GD (2008) Plant Propagation by Tissue Culture. Volume 1: The Background. Published by Springer, The Netherlands.

Giacometti DC and Leon J (1994) Tannia, yautia (Xanthosoma sagittifolium (L.) Schott). In: Neglected Crops 1492 from Different Perspectives, Hernandez-Bermejo L (Ed.), Food and Agricultural Organization of the United Nations, Rome, pp. 255-258.

Gomes F, Simões M, Lopes ML and Canhoto M (2010) Effect of plant growth regulators and genotype on the micropropagation of adult trees of Arbutus unedo L. (strawberry tree). New Biotechno. 27: 882-892.

Hazarika BN, Teixeira da Silva JA and Talukdar A (2006) Effective acclimatization of in vitro cultured plants: Methods, physiology and genetics. In: Floriculture Ornamental and Plant Biotechnology: Advances and Topical Issues, Silva JA (Ed.), Global Science Books, Ltd., Japan, pp. 427-438.

Ko C, Kung J and Donald R (2008) In vitro micropropagation of white dasheen (Colocassia esculenta (L.) Schott). Afric. J. Biotechnol. 7(1): 41-43.

Minitab (2013) Minitab Statistical Software, version 17, Minitab Inc., USA.

Niemenak N, Noah AM and Omokolo DN (2013) Micropropagation of cocoyam (Xanthosoma sagittifolium L. Schott) in temporary immersion bioreactor. Plant Biotechno. Repor. 7(3): 383390.

Obidiegwu EJ (2015) Towards genetic engineering in cocoyam food crop: Challenges and prospects. Adv. Genet. Eng. http://dx.doi.org/10.4172/2169-0111.1000121

Onokpise OU, Tambong JT, Nyochembeng L and Wutoh JG (1992) Acclimatization and flower induction of tissue culture derived cocoyam (Xanthosoma sagittifolium (L.) Schott) plants. Agronomie 12(2): 193-199.

Onokpise OU, Wutoh JG, Ndzana X, Tambong JT, Meboka MM, Sama AE, Nyochembeng L, Aguegia A, Nzietchueng S, Wilson JG and Burns M (1999) Evaluation of macabo cocoyam germplasm in Cameroon. In: Perspectives on New Crops and New Uses, Janick J. (Ed.), ASHS Press, Alexandria. pp. 394-396. 
Onyeka J (2014) Status of cocoyam (Colocasia esculenta and Xanthosoma spp.) in west and central Africa: production, household importance and the threat from leaf blight, Research Program on Roots, CGIAR, France.

Panell D (1984) The impact of micropropagation on commercial production. Sci. Hort. 35: 28-33.

Paul KK and Bari MA (2007) Protocol establishment for micropropagation and in vitro callus regeneration of Maulavi Kachu (Xanthosoma sagittifolium (L.) Schott) from cormel axillary bud meristem. J. Plant Sci. 2: 98-406.

Sama AE, Hughes HG, Abbas MS and Shahba MA (2012) An efficient in vitro propagation protocol of cocoyam (Xanthosoma sagittifolium (L.) Schott. The Sci. World J. http://org.doi:10.1100/2012/346595

Siddique I and Anis M (2009) Direct plant regeneration from nodal explants of Balanites aegyptiaca L. (Del.): a valuable medicinal tree. New Forests 37(1): 53-62.

Solomon T, Tesfaye B and Diro M (2010) In vitro and conventional propagation of Xanthosoma sagittifolium. Retrieved August 1, 2020, from www.ebay.com/vitro-conventional-Propagationof-Xanthosoma-sagittifolium

Vilchez J, Rivas Y, Albany N and Molina M (2009) Effect of the N6 -Benzylaminopurine on in vitro multiplication of cocoyam (X. sagittifolium (L.) Schott). Rev. Fac. Agrono. 26: 212-22.

Wokabi JN (2012). Establishment of an in vitro micropropagation protocol for farmer preferred cocoyam (Colocasia esculenta (L.) Schott) and (Xanthosoma sagittifolium (L.) Schott) cultivars grown in Kenya. MSc. Thesis, Applied Sciences of Kenyatta University, Nairobi, Kenya. 